\title{
Effects of Foreign Direct Investment on Growth in Turkey
}

\author{
Melike Bildirici, Yıldız Technical University \\ Elçin Aykaç Alp \\ Fazıl Kayıkçı, Yıldız Technical University
}

\begin{abstract}
This study aims at analyzing the relationship between Foreign Direct Investment and Growth in Turkey by using Threshold Cointegration. As the studies about the impact of Foreign Direct Investment on growth are surveyed, it is seen that all of them uses liner methods except two. Starting point of these studies that use liner methods are the positive relationship between Growth and Foreign Direct Investment. As such, Y1lmaz and Barbaros (2006) find positive relationship between Foreign Direct Investment and market size in Turkey between 1980 and 2001. Erdal and Tatoğlu (2002) reach the same conclusion for the period of 1980-1998 by using real Gross Domestic Product as a proxy for market size. Deichmann, Karidis and Sayek (2003) find positive linkage between Foreign Direct Investment and Gross Domestic Product in Turkey by using Conditional Logit Model. Bildirici and Bozoklu (2008) find positive relationship between growth and Foreign Direct Investment by using Markov Switching Vector Auto Regression method. Katırcioğlu (2009) analyses the connection between Foreign Direct Investment and economic development by using Auto Regressive Distributed Lag and indicates that economic development causes net Foreign Direct Investment. Darrat and Sarkar (2009) state the affirmative effects of the Foreign Direct Investment on growth as expected theoretically. Bildirici, Bozoklu (2008) find positive relationship between growth and Foreign Direct Investment in Turkey. Bildirici, Alp and Kayıkçı (2010) state the existence of threshold effect for these variables. This study intends to research this effect in historical perspective, using Threshold Cointegration Analysis.
\end{abstract}

JEL codes: C32, F21, F43

\section{Introduction}

While foreign direct investments (FDI) take place in two ways as a complete new investment (Greenfield) by corporate combinations and corporate take over (Merger and Acquisition), each definition carries different implications in itself. The conflict between the preference of foreign companies and the social benefit of host country sets a stage for intervention. Host country prefers new investments rather than corporate combinations.

According to researches which study the effects of foreign capital on the economy, effect of foreign capital on the economy is positive. Studies, which approach to the relationships between FDI and economic growth from the positive perspective, analyze the subject in the context of positive externalities. According to these studies, FDI flow provides direct and indirect profits to the incoming country because it has important positive externalities. This theory can be evaluated in two perspectives. It will be seen that for the relationship between economic growth and FDI, the traditional approach is depended on market imperfection approach (MIA) or industrial organization approach (IOA). In the base of MIA approach there are market imperfections. According to IOA, transferring of technology, marketing skills, management and other sources beyond capital, are essential in the perspective of FDI effect. According to Kindleberber (1969) returns of others are also important and deterministic as well as capital.

When positive externalities are to be evaluated, which are the adoption of foreign technology and know-how, which can happen via licensing agreements, imitation, employee training, the introduction of new processes, and products by foreign firms; and the creation of linkages 
between foreign and domestic firms, these are to enable country's national economy as modern by this way and to encourage economic growth, management and organization level, taxes, balance of payments, the encouragement of justice in income distribution. Blomstrom and Kokko (1998), Gorg and Greenway (2004), Lipsey (2002), Barba Navaretti and Venables (2004), and Alfaro and Rodriguez-Clare (2004) studies have focused on spillover channel of FDI.

The studies which question positive effect; Magnus Blomstom, Robert Lipsey and Mario Zejan (1994) emphasized that positive effect of FDI upon economic growth only appear in higher-income developing countries. Referring market growth, Bondera and White (1968), Schmitz and Bieri (1975), Swedenborg (1979), Lunn (1980), Dunning (1980), Root and Ahmed (1979), Kravis and Lipsey (1982), Nigh (1985), Schneider and Frey (1985), Culem (1988), Wheeler and Mody (1992), Sader (1993), Tsai (1994), Billington (1999), Pistoresi (2000) and Shamsuddin (1994) emphasized the existence of positive effects. Researches which study the effect on labor cost; while Caves (1974), Swedenborg (1979), Nankani (1979), Wheeler and Mody(1992) emphasize positive effect, Goldsrough(1979), Saunders(1982), Flam (1984), Schneider and Frey (1985), Culem (1988), Shamsuddin (1994), Pistoresi (2000) emphasized negative effects. Owen (1982), Gupta (1983), Lukas (1990), Rofle and White (1991), Sader (1993), Tsai (1994) found the effects as unimportant. Krevis and Lipsey (1982), Culem (1988), Edwards (1990), Pistoresi (2000) while emphasizing positive effects in openness matter, Schmitz and Bieri (1972) and Wheeler and Mody (1992) has specified the unimportance of the effect. When the effects have been researched upon exchange rate, while Edwards (1994) emphasizing positive, Caves (1988), Contractor (1990), Froot and Stein (1991), Bionigen (1995) and Bionigen and Freenstra (1996) emphasizig negative effetcs, Calderon and Rossel (1985), Sader (1991), Bloningen (1997) and Tuman and Emmert (1999) decleared the unimportance of effects. For the matters of taxes while Hartman (1984), Grubert and Muti (1991), Hines and Rice (1994), Loree and Guisinger (1995), Guisinger (1995), Cassou (1997), Kemsley (1998), Barrel and Paint (1998), Billington (1999) emphasize negative effects, Swenson (1994) found that the effects are positive. Luiz De Mello (1997), emphasized technological gap between the host and foreign country, and found that with the increase of technological gap the effect will be smaller (Spatz, Nunnenkamp;2004). When Abdul Khaliq and Ilan Noy (2007) studied the effect of FDI upon economic growth as sectoral, has found this effect to be positive on some parts of sectors and negative in most of sectors.

Some studies however, started to question the provision of the effects appearance. According to them; foreign companies may not always contribute to the appearance of effects to the country they come. As it does not provide technology transfer, effort may tend to turn to labor intensive manufacturing. The another important point, as Caves (1971, 1974), Saunders (1982), Gupta (1983), and Kumar (1987) emphasize in their studies, the arising rivalry in the case of specific production effect and the existence of imperfect competition market, is the loss of their advantages and the absence of countries' comparative advantages.

Some part of their studies emphasized the capacities of countries in benefiting from FDI externalities. These studies started to focus on the conditions of local circumstances. Within these local circumstances, development structure of financial markets, education level of country, the level of human capital investment has come to the forefront. Borensztein, De Gregorio, and Lee (1998) and Xu (2000) have axplained the effect of high technology of FDI upon economic growth with human capital investment. Alfaro et.all (2006), Durham (2004), and Hermes and Lensink (2003) tied the benefit of FDI which will provide to the country, to the developed financial markets. Balasubramanyam, Mohammed Salisu and David Sapsford (1996) has indicated that the openness to trade is the base in taking benefit from FDI. There is one important problem in the studies which emphasizes positive externalities between economic growth and FDI, that is the structural differences of foreign countries and calculation errors which are the usage of FDI stocks and flows interchangeably (Spatz, Nunnenkamp;2004). 
In the this study, foreign capital in Turkish economy will be studied in historical perspective; the third part is consists of from the econometric theory while the last part includes the discussions of the results.

\section{Foreign Investments in Turkish Economy}

Foreign investments coming after the establishment of Turkish Republic, took place as corporation and these corporations were generally in food, cement and textile sectors. There are 94 companies that can be considered as foreign capital in 1924. 23 of them are in banking, 11 in electricity, 12 in manufacturing industry, 35 in trading and 6 in marine fields. In the year of 1929, the number of foreign investment companies increased to 114 and 30 billion dollars capital has entered country. For the reasons of the lack of foreign capital, it is important to indicate there are important effects of I. World War, 1929 depression and nationalization. Since 1928, Turkish Government nationalized 24 foreign investment companies. In 1933-45 21 companies were nationalized.

Important developments emerged after 1950 in order to encourage foreign capital which was in low levels because of the effects of II. World War, nationalization and etatism policies. In the eventuation of international monetary fund (IMF) and the participation of Turkey to the World Bank (IBRD), its taking benefit from Marshall Plan, monetary and military help from the USA, Turkish Republic tended to make legislative amendments to make easier for foreign capitals to invest in Turkey (Karluk; 2001). It has been observed that these amendments resulted in forming a restrictive frame for foreign investors especially in 1960s and 1970s (Şenses ve Taymaz; 2003). After 1980 many changes have been made in codes of practice of incentive policies with the aim of encouragement of FDI. By these changes foreign companies were enabled to enter all sectors and access the whole property rights (Öniş (1994) Erdilek (1982). Namely, for the purpose of encouragement of direct investment, foreign investment legislation has been rescheduled after 1980. In the years of 1986, 1992 and 1995, changes made in foreign investment framework decision, the legislation became more liberal and customs unions negotiated with the EU in 1996 and the international arbitration in 1999 inured (TCMB, 2000, 52). Nevertheless, expected increase could not be observed in the movements of foreign capital especially the increase awaited from direct investment. By the consideration of encouragement validated for foreign investment as well, native and foreign companies started to take benefit from encouragement practices equally. Namely, amendments and globalization in 1984 and 1990 periods have been essential in short term and portfolio investments. As a matter of fact, short term and portfolio investments produced important effects after 1990s. Such that, Turkish economy grown in the years when short term and portfolio investments were positive. As a result of inversion of the entrance of short term and portfolio investments by depression in 1994, economy has decreased in 6.1\% (Uygur, 1999). Portfolio and short term investment, inversion of foreign capital can be seen as a cause of depression in 1999 and 2000-01 crises. When the effects of 2001 crises started to be partly overcome, foreign capital began to enter. FDI investment entered these years was very limited.

With the laws concerning international arbitration made in years 2000 and 2001, an ambiance was created where all obstacles for foreign investments were defeated. While in 2002 1,1 billion $\$$ foreign capital entered the country, this amount was 2,8 billion $\$$ in 2004 and this development turned to a remarkable leap and direct investments increased to 20 billion $\$$ in 2006 and 21,9 billion \$ in 2007.

Although a leap has been seen in direct investments between the years 2004-2008, these are the results of privatization rather than new investments. However, these rates were insufficient. As a matter of fact, when FDI dispersion is studied for the years 2005 and 2006, Turkey can be seen in 23rd and 16.th row in turn.

As it can be seen from the Table 1, without considering China and Hong Kong, we can see that industrialized countries took a share from FDI. Although with 9.80 billion \$ capital Turkey 
took place in 23rd row in 2005, and tough rose to 16th row in 2006 by 2010 billion $\$$ capital, when privatizations are considered, it can bee seen that foreign capital investments as a form of new investments were lower and sufficient foreign capital could not be obtained.

When the features of direct foreign capital investments are studied;

The incoming direct investment is as predominantly owner's equity investment. Owner's equity investment which was 3352 billion \$ in 2001, has increased to 21864 billion \$ in 2007 . When the periods 2009 October-May and 2010 October-May are studied, it can be seen that the values are 3861 and 2562 respectively.

When the numbers of firms are studied, an increase is seen after 2000. When there were total 4141 companies between the years 1954-1999 cumulatively, 3352 companies came in 2000, the increase of foreign investment 2004 also was seen here, 2095 companies which came in 2004 reached to 3530 in 2007 . With the effects of crises of 2008 decrease continued also in 2009 and 2010 and 3337, 2987 and 1252 companies were established respectively. In two last years, the number of companies founded was decreased $10 \%$ and $55 \%$ when compared to previous year (Treasury, Turkish Republic:2010).

As per 2010 June, 20386 international investment companies branches were established, 4669 local investment companies participation to international investment took place. In total 24924 international investment companies are operated in our country. The inadequacy of the number is clear (Treasury, Turkish Republic:2010).

Most of the foreign direct capital has come to services sectors as $90.2 \%$ in $2005,90.6 \%$ in 2006, 69.9\% in January-October 2007. Share of production sector as $60.1 \%$ in 2003 persistently decreasing to $8 \%$ until 2006 , increased to $23.6 \%$ in January-October 2007 . The leading sector in capital outflow is manufacturing industry $(89.7 \%$ in $2005,76.7 \%$ in 2006). It decreased to 24\% in January-October 2007 (DPT, 2008). Namely, when sectoral dispersion of foreign capital is studied, finance sector and manufacturing industry stand out.

It is seen that (Table 2) 25055 international firms operate in heading wholesale and retail trade, manufacturing industry, real estate renting and business operation sectors. While chemical materials and products are leading in international investment companies which operate in manufacturing industry, food products, beverages and tobacco manufacturing with textile products follows. However, number of firms operate in the manufacturing sector can still be considered as insufficient when compared to the service sectors.

Approximately $55 \%$ of foreign capitals are centered in Istanbul. Antalya takes second place by $12 \%$, Ankara takes 3rd place by $6 \%$ and Izmir takes fourth place by $5 \%$. It is not possible to mention about a broad based investment in Turkey.

When we look at dispersion of foreign capital according to the countries (Table 3), it is seen that particularly Netherlands, Germany, EU countries and USA take most shares. Asian countries fallow these countries.

As it can be seen when FDI is studied in Turkish economy; it is observed that the incoming investments are insufficient, that they are focused in Istanbul and display an increasing structure in services sector. Total of foreign direct investment in 2001-2007 period is 50.8 billion \$. Total profit transfers are $10 \%$ of direct investments. While this rate is $58 \%$ when profit transfer was in its highest rate in 2004, it is seen that the same rate were decreased to 6$9 \%$ levels between the years 2005 and 2006, and increased to $10 \%$ in 2007 .

\section{Econometric Methodology}

This study based on the usage of TAR cointegration method. The reason of the preference of this method is especially the thought of short term capital flows' openness to threshold effect. Two regimes threshold model can be written as $\gamma$ threshold parameter, 


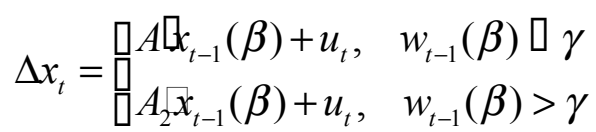

it can also be written as below.

$\Delta x_{t}=A_{1} x_{t-1}(\beta) d_{1 t}(\beta, \gamma)+A_{2} x_{t-1}(\beta) d_{2 t}(\beta, \gamma)+u_{t}$.

$\mathrm{I}($.$) as an indicator function,$

$$
d_{1 t}(\beta, \gamma)=I\left(w_{t-1}(\beta) \square \gamma\right), d_{2 t}(\beta, \gamma)=I\left(w_{t-1}(\beta)>\gamma\right)
$$

There are two regimes defined according to second equation's error term level. A1 and A2 coefficients' matrix are sheltered in these two regime dynamics. 2. model provides all parameters to be changed among these two regimes. In the case of only $0<\mathrm{P}\left(w_{t-1} \leqslant \gamma\right)<1$ threshold effect exists, it will turn to linear coentegration in other cases. By being $\pi_{0}>0$ trimming parameter, it is constructed as it is defined in 3 . equation.

$$
\pi_{0} \leqslant \mathrm{P}\left(w_{t-1} \leqslant \gamma\right) \leqslant 1-\pi_{0},
$$

\section{Data and Econometric Results}

The data used in the study has been taken from Turkish Statistical Institute (TUIK), Central Bank of Turkey (TCMB) electronic data delivery service. Growth data has been calculated as proportional increase in industrial production index. The scope of data is monthly between 1992:01 and 2008:12.

As a measurement of economic growth in this work, industrial production index was taken in terms of GDP growth. Although it is a common application to use GDP as a measurement concerning the works of relating FDI with economic growth, we will take action from industrial production index as the works of Bildirici, Alp and Kayıkçı(2010). There are two reasons for the usage of IPI in economic growth. The first one is that IPI representation can be the measurement of economic growth, because the correlation between IPI and GDP is found as 0.80 . The second is that it is aimed at seeing the FDI effect on industrial production.

The works apply GDP variable, and also use linear models usually. The works conducted for Turkish economy, the works of Bildirici and Bozoklu (2008) and Bildirici, Alp and Kayıçı (2010) are the works which use nonlinear methods. In this study, as in the study of Bildirici, Alp and Kayıkçı (2010) Threshold structure was attached to the main body of the empirical work and TAR Cointegration analysis was applied. By the application of TAR analysis, cointegration analysis will be analyzed by the values under and above threshold level.

\begin{tabular}{|c|c|c|c|c|}
\hline & Test Statistic & $1 \%$ & $5 \%$ & $10 \%$ \\
\hline -D(FDI)- & -12.43681 & -3.465977 & -2.877099 & -2.575143 \\
\hline -D(Growth)- & -5.389460 & -3.467205 & -2.877636 & -2.575430 \\
\hline
\end{tabular}

Table 4: Traditional Unit Root Test Results for FDI and Growth (ADF Test)

As it can be seen from the table, both foreign capital and growth series are integrated of order one. Lag lengths are determined according to AIC information criterion. (Information was previously given that the power of unit root tests might be low in the case of nonlinear structure, and it should be tested with Caner- Hansen (2001) TAR unit root tests which was developed for these cases).

The numbers in brackets in the estimated Threshold VAR models are Eicker - White standard errors. When the models are studied, parameter estimations are statically significant. For parameters $\gamma, \beta$ scan size has been chosen as $300 \times 300$ and estimated co integration relationship as a result of likelihood function has been found as $v_{t}=G_{t-1}+0,35 F D I_{t}$ and 
estimated threshold value has been found as $\hat{\gamma}=-0,69$. Therefore, the first regime arises in the case when foreign capital shown $96 \%$ more decline rather than growth. In the estimated period, first regime comprises $20 \%$ of the observations and is called as extreme regime. Second regime comprises $80 \%$ part which above normal and called as typical regime. Second regime arises in the cases when the difference between foreign capital and growth decreases less than $69 \%$, or becomes stable or decrease.

First regime "extreme regime" $G_{t},-0,35 F D I_{t}-0,69$

Second regime "typical regime" $G_{t}>-0,35 F D I_{t}-0,69$

Estimated VAR model,

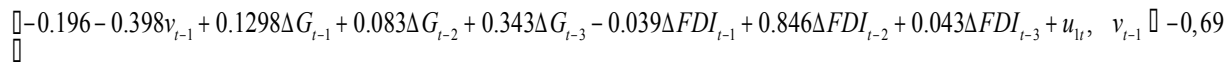

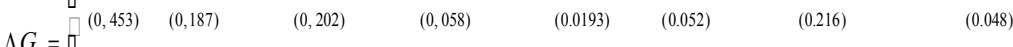

$$
\begin{aligned}
& \Delta G_{t}=0.458-0.315 v_{t-1}-0.358 \Delta G_{t-1}+0.0008 \Delta G_{t-2}+0.103 \Delta G_{t-3}-0.016 \Delta F D I_{t-1}+0.1888 \Delta F D I_{t-2}-0.021 \Delta F D I_{t-3}+u_{2 t}, \quad v_{t-1}>-0.69 \\
& \square(0,148) \quad(0,074) \quad(0,088) \quad(0,023) \quad(0.0975) \quad(0.0206) \quad(0.068) \quad(0.015) \\
& {\left[-1.273-3.66 v_{t-1}-0.617 \Delta G_{t-1}-0.698 \Delta G_{t-2}+0.282 \Delta G_{t-3}-0.348 \Delta F D I_{t-1}+0.879 \Delta F D I_{t-2}-0.221 \Delta F D I_{t-3}+u_{1 t}, \quad v_{t-1}[-0,69\right.}
\end{aligned}
$$

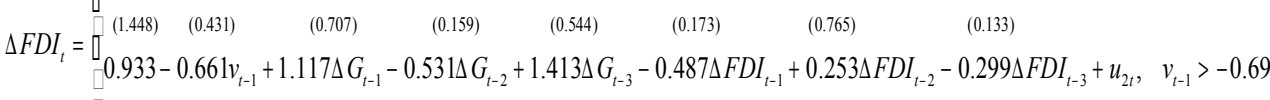

$$
\begin{aligned}
& \begin{array}{llllllll}
(0.654) & (0.293) & (0,331) & (0.119) & (0.440) & (0.133) & (0.286) & (0.112)
\end{array}
\end{aligned}
$$

When the equations are analyzed, it can be seen that in the first regime which observation values comprise $20 \%$ and called as extreme regime, error correction mechanism operates in the first equation and it was insignificant in the second equation. In second regime, it can operate in both equations. Thus, it is concluded that obtained co integration relationship is valid for both regimes.

\section{Conclusion}

In this study, it was analysed the relationship between Foreign Direct Investment and Growth in Turkey by using Threshold Cointegration The relationship shows as a result of analyzing the period of 1992:01-2008:12 that, in the cases in which foreign capital decrease above $70 \%$, there will be $35 \%$ decrease in growth and this is a quite remarkable decline.

Annex
\begin{tabular}{|c|c|c|c|}
\hline Country & 2005 & Country & 2006 \\
\hline 1-England & 193,7 & 1-England & 175,4 \\
\hline 2-U.S.A. & 101 & 2-U.S.A. & 139,5 \\
\hline 3-France & 81,1 & 3-France & 81,1 \\
\hline 4-China & 72,4 & 4-China & 72 \\
\hline 5-Netherlands & 41,6 & 5-Netherlands & 69,5 \\
\hline 6-Germany & 35,9 & 6-Germany & 69 \\
\hline 7-Belgium & 35,9 & 7-Belgium & 42,9 \\
\hline 8-Hong Kong & 33,6 & 8-Hong Kong & 42,9 \\
\hline 9-Canada & 28,9 & 9-Canada & 39,2 \\
\hline 10-Spain & 25 & 10-Spain & 29,3 \\
\hline 23-Turkey & 9,8 & 16-Turkey & 20,1 \\
\hline
\end{tabular}

Table 1. FDI Shares in the World (Billion \$). Source: Under secretariat of Treasury, Turkish Republic 


\begin{tabular}{|c|c|c|c|c|c|c|c|}
\hline & $1954-2004$ & 2005 & 2006 & 2007 & 2008 & 2009 & $\begin{array}{c}1954- \\
2010 \\
\text { June }\end{array}$ \\
\hline & Cumulative & & & & & & Total \\
\hline $\begin{array}{l}\text { Agriculture, hunting, fishing } \\
\text { and forestry }\end{array}$ & 131 & 34 & 42 & 49 & 53 & 60 & 387 \\
\hline Mining and quarrying & 138 & 50 & 48 & 82 & 91 & 71 & 510 \\
\hline Manufacturing & 1937 & 400 & 441 & 497 & 471 & 384 & 4311 \\
\hline $\begin{array}{l}\text { Manufacture of food products } \\
\text { and beverages }\end{array}$ & 233 & 39 & 43 & 38 & 38 & 49 & 481 \\
\hline Manufacture of textiles & 242 & 66 & 50 & 49 & 21 & 18 & 452 \\
\hline $\begin{array}{c}\text { Manufacture of chemicals and } \\
\text { chemical products }\end{array}$ & 232 & 37 & 39 & 58 & 48 & 39 & 483 \\
\hline $\begin{array}{c}\text { Manufacture of machinery and } \\
\text { equipment }\end{array}$ & 145 & 27 & 54 & 46 & 46 & 24 & 353 \\
\hline $\begin{array}{c}\text { Manufacture of motor vehicles, } \\
\text { trailers and semi-trailers }\end{array}$ & 141 & 21 & 17 & 23 & 21 & 18 & 242 \\
\hline Other Manufacturing & 944 & 210 & 238 & 283 & 297 & 236 & 2298 \\
\hline $\begin{array}{l}\text { Electricity, gas and water } \\
\text { supply }\end{array}$ & 89 & 9 & 42 & 75 & 117 & 132 & 514 \\
\hline Construction & 338 & 312 & 404 & 477 & 372 & 302 & 2331 \\
\hline Wholesale and retail trade & 3048 & 708 & 752 & 808 & 791 & 933 & 7491 \\
\hline Hotels and restaurants & 710 & 162 & 194 & 207 & 220 & 174 & 1746 \\
\hline $\begin{array}{c}\text { Transport, storage and } \\
\text { communications }\end{array}$ & 691 & 222 & 266 & 284 & 292 & 268 & 2172 \\
\hline $\begin{array}{l}\text { Real estate, renting and } \\
\text { business activities }\end{array}$ & 658 & 487 & 660 & 828 & 675 & 476 & 4002 \\
\hline $\begin{array}{l}\text { Other community, social and } \\
\text { personal service activities }\end{array}$ & 331 & 167 & 226 & 223 & 255 & 187 & 1294 \\
\hline TOTAL & 8192 & 2551 & 3075 & 3530 & 3337 & 2987 & 25055 \\
\hline
\end{tabular}

Table 2. FDI dispersion According to the Sectors. Source: Under secretariat of Treasury, Turkish Republic

\begin{tabular}{|c|c|c|c|c|c|c|c|}
\hline & $\begin{array}{c}1954- \\
2004\end{array}$ & 2005 & 2006 & 2007 & 2008 & 2009 & $\begin{array}{c}1954- \\
2010 \\
\text { June }\end{array}$ \\
\cline { 2 - 9 } & $\begin{array}{c}\text { Cumulativ } \\
\mathrm{e}\end{array}$ & & & & & & Total \\
\hline European Union (27) & 4182 & 1513 & 1926 & 2027 & 1770 & 1423 & 13417 \\
\hline Germany & 1405 & 462 & 540 & 557 & 584 & 513 & 4256 \\
\hline The Netherlands & 652 & 189 & 257 & 249 & 277 & 146 & 1842 \\
\hline United Kingdom & 536 & 297 & 453 & 436 & 251 & 205 & 2256 \\
\hline Other European Countries & 1589 & 565 & 676 & 785 & 658 & 559 & 5063 \\
\hline Other European Countries & & & & & & & \\
(Exclude EU) & 981 & 311 & 356 & 471 & 528 & 431 & 3305 \\
\hline Africa & 146 & 52 & 42 & 48 & 50 & 66 & 448 \\
\hline North America & 496 & 104 & 132 & 160 & 142 & 148 & 1241 \\
\hline U.S.A. & 453 & 90 & 111 & 127 & 124 & 116 & 1071 \\
\hline Canada & 43 & 14 & 21 & 33 & 18 & 32 & 170 \\
\hline Central-South America And & 54 & 14 & 11 & 20 & 12 & 17 & 134 \\
\hline
\end{tabular}




\begin{tabular}{|c|c|c|c|c|c|c|c|}
\hline Caribbean & & & & & & & \\
\hline $\begin{array}{c}\text { Near and Middle Eastern } \\
\text { Countries }\end{array}$ & 1657 & 375 & 396 & 492 & 564 & 639 & 4464 \\
\hline Azerbaijan & 177 & 54 & 82 & 118 & 131 & 168 & 792 \\
\hline Iraq & 249 & 56 & 70 & 107 & 86 & 106 & 719 \\
\hline Iran & 540 & 118 & 104 & 103 & 140 & 173 & 1308 \\
\hline Other & 691 & 147 & 140 & 164 & 207 & 192 & 1645 \\
\hline Other Asian Countries & 574 & 159 & 163 & 271 & 229 & 239 & 1753 \\
\hline China & 191 & 30 & 24 & 41 & 44 & 43 & 392 \\
\hline South Korea & 74 & 16 & 13 & 23 & 13 & 21 & 167 \\
\hline Other & 309 & 113 & 126 & 207 & 172 & 175 & 1194 \\
\hline Other Countries & 102 & 23 & 49 & 41 & 42 & 24 & 293 \\
\hline TOTAL & 8192 & 2551 & 3075 & 3530 & 3337 & 2987 & 25055 \\
\hline
\end{tabular}

Table 3. FDI dispersion According to the Countries. Source: Under secretariat of Treasury, Turkish Republic

\section{References}

- $\quad$ Alfaro, Chanda, Kalemli-Ozcan and Sayek 2006. "How Does Foreign Direct Investment Promote Economic Growth? Exploring the Effects of Financial Markets on Linkages" http://hbswk.hbs.edu/item/5531.html

- Bandera, and White 1968. "U.S. Direct Investments and Domestic Markets in Europe”, Economia Internazionale. 21, p. 117-133.

- Barrel and Pain 1998. "Real Exchange Rates, Agglomerations, and Irreversibilities: Macroeconomic Policy and FDI in EMU",Oxford Review of Economic Policy 4, p.152-167.

- Billington, 1999. "The Location of Foreign Direct Investment: An Empirical Analysis", Applied Economics. 31, p. $65-76$.

- Bildirici, Aykaç Alp, Ersin and Bozoklu 2010: “íktisatta Kullanılan Doğrusal Olmayan Zaman Serisi Yöntemleri”,Türkmen Kitabevi, İstanbul.

- $\quad$ Bildirici and Bozoklu 2008: "Yabancı Sermayenin Ekonomi Üzerindeki Etkilerinin MS-VAR Yöntemi Kullanılarak Test Edilmesi”, in proceedings of ICAM 2007, Balıkesir.

- Caner, and Hansen 2001: "Treshold autoregressions with a unit root," Econometrica, 69, p. 1555-97.

- Cassou, 1997. "The Link Between Tax Rates and Foreign Direct Investment, Applied Economics". 29, p. 1295 -1301.

- Chakrabarti, 2001. "The Determinants of Foreign Direct Investment: Sensitivity Analyses of Cross-Country Regressions", Kyklos, 54(1), p. 89-113.

- Cheng, and Kwan 2000. "The location of foreign direct investment in Chinese regions, further analysis of labor quality. The Role of foreign direct investment in East Asian economic development", NBER, p. 213-238.

- Coughlin, Terza and Arromdee 1991. "State Characteristics and the Location of Foreign Direct Investment within the United States", The Review of Economics and Statistics, 734, p. 675-83.

- Culem, 1988. “The Locational Determinants of Direct Investments Among Industrialized Countries", European Economic Review, 32, p. 885-904.

- Deichmann Karidis and Sayek 2003. "Foreign Direct Investment in Turkey: Regional 
Determinants", Applied Economics, 35, no.16/10, p. 1767-78.

- Dunning, 1980. "Toward an Eclectic Theory of International Production: Some Empirical Tests", Journal of International Business Studies, 11, p. 9-31.

- Edwards, 1990. "Capital Flows, Foreign Direct Investment, and Debt-Equity Swaps in Developing Countries”, NBER Working Paper No. 3497.

- Erdilek, 1982, "Direct Foreign Investment in Turkish Manufacturing J.C.B. Mohr, Tübingen.

- Flamm, 1984. "The Volatility of Offshore Investment", Journal of Development Economics, 16 p. 231- 248.

- Froot, and Stein 1991. "Exchange Rates and Foreign Direct Investment: An Imperfect Capital Markets Approach”, Quarterly Journal of Economics. 106 p. 1191-1217.

- Goldsbrough,1979."The Role of Foreign Direct Investment in the External Adjustment Process", International Monetary Fund Staff Papers, 26 p. 725 -754.

- Grubert and Mutti 1991. "Taxes, Tariffs and Transfer Pricing in Multinational Corporate Decision Making”, Review of Economics and Statistics, 73 p. 285-293.

- Gupta, 1983. "A Simultaneous Determination of Structure, Conduct and Performance in Canadian Manufacturing", Oxford Economic Papers. 35, p. 281-301.

- Hartman, 1984. "Tax Policy and Foreign Direct Investment in the United States", National Tax Journal. 37, p. 475-487.

- Hines, and Rice 1994. "Fiscal Paradise: Foreign Tax Havens and American Business", The Quarterly Journal of Economics, 109, p. 149-182.

- $\quad$ ITO 2010. "2009 Yılı Yeni Kayıt ve Kapanış Yaptıran Firmalarda Yabancı Yatırımeı ve Sermaye Durumu" Ireport.

- Karluk 2001. “Türkiye'de Yabancı Sermaye Yatırımlarının Ekonomik Büyümeye Katkısı", Ekonomik Istikrar, Yabanc1 Sermaye ve Büyüme, TCMB.

- Khaliq, and Noy. 2007, Foreign Direct Investment and Economic Growth: Empirical Evidence from Sectoral Data in Indonesia,

- Kemsley, 1998. "The Effect of Taxes on Production Location", Journal of Accounting Research, 36 p. 321-341.

- Kindleberger , 1969. “American Business Abroad: Six Lectures on Direct Investment, Fourth Printing", Yale University Press, New Haven.

- Kravis, and Lipsey 1982. "The Location of Overseas Production and Production for Export by U. S. Multinational Firms", Journal of International Economics, 12, p. 201223.

- Loree, and Guisinger 1995. "Policy and Non-Policy Determinants of U.S. Equity Foreign Direct Investment”, Journal of International Business Studies, 26, p. 281300 .

- Lucas. 1993. "On the Determinants of Direct Foreign Investment: Evidence from East and South Asia", World Development, 21, p. 391-406.

- Lunn, 1980. "Determinants of U. S. Direct Investment in the E. E. C.: Further Evidence", European Economic Review, 13, p. 93-101.

- Nankani, 1979. “The Intercountry Distribution of Direct Foreign Investment”. Garland, New York.

- Nigh, 1985. "The Effect of Political Events on United States Direct Foreign Investment: A Pooled Time-series Cross-sectional Analysis", Journal of International Business Studies. 16, p. 1-17. 
- Onyeiwu and Shrestha 2004. "Determinants of Foreign Direct Investment in Africa" Journal of Developing Societies, 20 (1-2), p. 89-106.

- Owen, 1982. "Inter-industry Determinants of Foreign Direct Investments: A Canadian Perspective", in A. M. Rugman ed., New Theories of Multinational Enterprise. London.

- Öniş, 1994. "Liberalization, Transnational Corporations and Foreign Direct Investment in Turkey: The Experience of the 1980s", in Şenses 1994, p. 91-109.

- Pistoresi, 2000. “Investimenti diretti esteri e fattori di localizzazione: L'America Latina e il SudEst asiatico", Rivista di Politica Economica, 90, p. 27-44.

- Root, and Ahmed 1979. "Empirical Determinants of Manufacturing Direct Foreign Investment Developing Countries", Economic Development and Cultural Change, 27 p. $751-767$.

- Sader, 1993. "Privatization and Foreign Investment in the Developing World", World Bank Working Paper No. 1202.

- Saunders, 1982.“The Determinants of Foreign Direct Investment”, Canadian Journal of Economics, 15p77-84.

- Schmitz, and Bieri, 1972. EEC Tariffs and U. S. Direct Investment”, European Economic Review, 3, p.259-270

- Schneider, and Frey 1985. „Economic and Political Determinants of Foreign Direct Investment”, World Development, 13, p. 161-175.

- Shamsuddin, 1994. "Economic Determinants of Foreign Direct Investment in Less Developed Countries", The Pakistan Development Review, 33, p. 41-51.

- Spatz, and Nunnenkamp 2004. "FDI and economic growth in developing economies: how relevant are host-economy and industry characteristics?", Kiel Working Papers, no. 1176.

- Swedenborg, 1979. "The Multinational Operations of Swedish Firms: Analysis of Determinants and Effects", Working Paper, Industrial Institute of Economic and Social Research, Stockholm.

- Swenson, 1994. "The Impact of U. S. Tax Reform on Foreign Direct Investment in the United States", Journal of Public Economics, 54, p. 243-266.

- Tsai, 1994. "Determinants of Foreign Direct Investment and Its Impact on Economic Growth, Journal of Economic Development", 19, p. 137-163.

- Tuman, and Emmert 1999. "Explaining Japanese Foreign Direct Investment in Latin America, 1979 -1992”, Social Science Quarterly, 80, p. 539-555.

- Wheeler and Mody 1992. "International Investment Location Decisions: The Case for U.S. Firms", Journal of International Economics, 33, p. 57-76. 